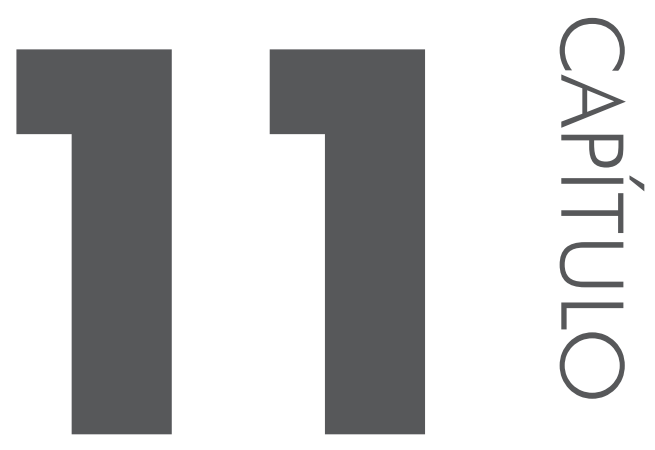

\title{
Vontades de nação e ambivalências ao sul de Angola: o romance Yaka
}

\author{
Frank Marcon \\ Universidade Federal de Sergipe
}

O escritor Pepetela publicou Yaka no ano de 1984. O romance trata da história de uma família estabelecida ao sul de Angola, a partir da chegada de Óscar Semedo, como degredado português, no ano de 1880. Daí em diante, Alexandre Semedo, seu filho, nascido em terras cuvale, será o principal protagonista. O livro é dividido em quatro capítulos: A Boca (1890/1904), Os Olhos (1917), O Coração (1940/41), O Sexo (1961) e As Pernas (1975). Todos os capítulos têm alguma relação com as partes do corpo de uma estátua Yaka, que observa e narra a trajetória de vida de Alexandre e sua família ao mesmo tempo em que metaforiza a nação como corpo e aponta cronologias do processo de colonização ao sul de Angola e a relação de tal região com os dilemas de uma ideia de nação sendo forjada a partir de processos históricos.

Em meio às narrativas que se sucedem sobre a saga da família Semedo, Pepetela segue ambientando o leitor sobre a geografia e o clima da região, com nomes de lugares, de rios e nomeando a fauna e a flora. Além disso, ele descreve as populações que vivem no Sul, seus hábitos, suas histórias e as relações entre os diferentes grupos humanos que se movimentaram por lá no curso de um século da vida do protagonista Alexandre. Pepetela constrói um romance em que a estátua Yaka se torna a narradora, mas também a principal interlocutora do protagonista, por 
vezes fazendo o papel do que parece ser sua dupla consciência, que uso aqui no sentido que Gilroy (2001) dá ao termo, de quem pensa a partir de duas lógicas distintas e contraditórias, que paradoxalmente se encontram e só é possível pela coexistência de seus opostos. Nesse sentido, a perspectiva dos Semedo é aquela que é mediada pela da estátua e pelos personagens do romance como narrativa plurivocal sobre o país.

O objetivo desse texto é analisar como tal romance é um registro muito peculiar sobre a região e, ao mesmo tempo, uma obra ficcional carregada de desejos de simbolização sobre a nação idealizada. Colonialismo, racismo, nacionalismo e etnocentrismos emergem de tal narrativa como interessantes formas de dizer sobre diversas experiências humanas de identificação e diferenciação em contextos de fronteira, de fluidez e de transumância. No romance, se exibem as contradições, as ambiguidades e as proximidades de processos de constituição de um desejo, o de se viver juntos, como projeto de futuro que mira o passado. Nesse caso, o romance, escrito nos anos 1980, olha para a possibilidade de dar sentido a uma narrativa sobre o que poderia ter sido a nação no seu pretérito remoto ou recente, mas também como um vir a ser.

São relações de poder, hierarquias, conflitos, processos de identificação e contradições morais e políticas que, ao mesmo tempo em que são narradas, dão visibilidade aos contrastes e aos desejos do autor do romance e dos sujeitos imaginados por sua escrita. Quem são eles? O que eles dizem e fazem? Como são imaginados por Pepetela? Por que eles compõem a narrativa de Yaka? Que nação é essa imaginada a partir do sul de Angola? Que Sul é esse imaginado a partir da ideia de nação? Como esse romance se constituiu numa narrativa sobre experiência social plural, de tensões e de mobilidades na região, numa perspectiva anticolonial, porém marcada pela (des)colonização?

\section{O romance e o autor}

O livro Yaka foi publicado pela primeira vez no Brasil, pela Editora Ática, no ano de 1984, pela Coleção Autores Africanos, em seguida, ao mesmo tempo em Angola, pela União dos Escritores Angolanos, e em Portugal, pela editora Dom Quixote. Depois, o livro teve várias reedições e tiragens em português e foi traduzido em vários idiomas para outros países, atingindo as dezenas de milhares em exemplares. Cabe ressaltar que, até o período em que foi publicada a primeira edição do livro, Pepetela era membro do governo e do partido MPLA, ocupando o cargo de vice-ministro da educação de Angola.

Em entrevista que realizei com Pepetela, no ano de 2003 (Marcon, 2005), ele diz que "O Yaka é do ponto de vista de uma perspectiva nacional, apesar de estar a contar a história de uma família colonialista. Para isto tive que estudar bastante 
a documentação que existia na época ou eu tinha disponível”. Algo que também se percebe na sua obra pela preocupação com a verossimilhança e alguma intencionalidade sobre a construção de uma narrativa sobre Angola, enquanto nação, mas também sobre o Sul (como estratégia de inclusão), território ameaçado por invasões sul-africanas nos anos 1970.

$\mathrm{Na}$ mesma entrevista, Pepetela deu mais indícios sobre a intenção com o romance e falou sobre como surgiu a ideia do livro:

[...] em 1975, estávamos numa guerra com os sul-africanos e UNITA, FNLA, etc., em Benguela, e um dia numa conversa, naquelas conversas longas antes de uma batalha - que o pessoal passa a noite inteira a conversar a espera para no dia seguinte de manhã entrar em ação - eu estava a conversar com um camarada que já morreu e que me disse: eu sou um tipo com muita sorte porque eu vivi uma situação colonial numa família de origem colonial, quer dizer eu conheci o colonialismo do lado do colonizador, depois combati este sistema e estive e vivi, convivi, comi e dormi com os colonizados e agora, neste momento, no sítio onde eu nasci, em Benguela, estou a assistir o fim absoluto do sistema colonial.

Quando entrevistado em 2003, Pepetela ressaltava que o livro surgira a partir de suas experiências biográficas, familiares, sociais e políticas, embora implicadas pela imaginação e pela experiência com a história documentada e oral. Concordo com Luis Kandjimbo (1997), em Apologia a Kalitangi, quando diz sobre Yaka que o romance está atento ao significado dos momentos históricos, mas não como historicidade de semântica colonial, ironizando os significados do luso-tropicalismo e do discurso multirracial. Para Kandjimbo, as referências históricas de Pepetela aos conflitos e aos contextos dos colonialismos são de alguma maneira uma estratégia para marcar um "pós" e dialogar com os problemas contemporâneos em que o autor referencia uma realidade projetada no passado (KANDJIMBO, 1997, p. 49). Sua principal crítica é deferida em direção ao tratamento imaginativo de Pepetela à questão da centralidade da família colonial no romance, como o que seria para Kandjimbo uma referência ideológica e maniqueísta da constituição da nação, o que nem todos os críticos do autor ou do romance concordam, embora as ambiguidades dessa interpretação levem os significados de Yaka a caminhos distintos.

De qualquer modo, muitos críticos concordam que a produção literária da descolonização legitimou novas perspectivas narrativas sobre a nação, como que tendo o papel de recontar, pela literatura, as histórias invisibilizadas pelo colonialismo. No caso específico de Pepetela, o autor marca a sua narrativa com o que seriam "sinais reconhecíveis de historicidade" ou de "realismo", quando inclui fatos ou personagens lendários, míticos ou históricos em seus romances. 
Roland Barthes (2004) denominaria esse trato narrativo de efeito de real, como que afetado por possibilidades de uma versão factível e acreditável, a partir das referências às pessoas, aos fatos e aos lugares reconhecíveis pelas experiências reais reproduzidas pela oralidade e pelo costume. A narrativa ganha assim estatuto legítimo de quem verbaliza algo crível. Em conversa informal com o sociólogo Nelson Pestana, em 2003, este diz que acredita que Yaka é um romance de virada na literatura de Pepetela, quando ele estaria definindo o seu projeto literário para um projeto de recontar a história do país incluindo-se como parte dele, ou incluindo a narrativa de sua origem no contexto narrativo de Angola, em que muitos também necessitavam se encontrar, para justificar uma idealização comum sobre a nação que precisava ser simbolizada, construída e imaginada com base em alguma coerência coletiva.

Para Ana Mafalda Leite (1996), a obra Yaka é também uma narrativa com questões históricas, atentas ao reexame da realidade social e cultural, nesse caso de Benguela e do sul de Angola. Para Leite (1996), a ambição de Pepetela é mostrar como uma família portuguesa branca aos poucos se torna ou pode se tornar (mesmo que só alguns) angolana. Alexandre Semedo e toda a sua prole nascem em Angola e cada um vai seguir a sua vida como angolano, branco, mulato ou negro, na política ou na economia, às vezes em lados ideológicos opostos. A nação é o encontro dessas possibilidades e a opção de construir um lugar de solidariedade, no qual o que define quem faz ou não parte desta não é cor, a raça ou o idioma, mas a consciência política, o sentimento e o reconhecimento, como o autor acabará por desenvolver no romance.

\section{Narrativas, ambivalências e dupla consciência}

Pepetela inicia o romance narrando o nascimento de Alexandre: "O primeiro vagido de Alexandre Semedo estalou em terra cuvale”. Depois, na perspectiva narrativa do próprio Alexandre:

Nasci em 1890, embaixo duma árvore. A minha mãe foi assistida pela velha Ntumba, escrava Ganguela. A escrava, talvez por velhice, me deixou cair no pó. Segundos apenas. Os suficientes para no meu corpo ficar misturado o pó da terra e os líquidos que trazia comigo ao sair da mãe.

Mais à frente, é a estátua quem narra o mesmo acontecimento:

Ouvi o grito de Alexandre Semedo a rasgar as entranhas da mãe e sair para a luz. [...] Vi a boca do menino morder a terra seca. Mordeu ou beijou? [...] Estou para ver. E contar para quem entende. Sofrendo. 
Neste último trecho, a estátua Yaka assume uma perspectiva narrativa onisciente, como perspectiva crítica da ingenuidade de Alexandre, sem que ele ainda o saiba. No entanto, antes de iniciar propriamente a história, Pepetela alerta ao leitor em "Nota Prévia", sobre o quê ou quem é Yaka:

[...] E o círculo yaka ficou fechado nesses séculos antigos. Criadores de chefias, assimiladores de culturas, formadores de exércitos com jovens de outras populações que iam integrando na sua caminhada, parecem apenas uma idéia errante, cazumbi antecipado da nacionalidade.

Mas não é deles que trata este livro, só duma estátua.

E a estátua é pura ficção. Sendo a estatuária yaka riquíssima ela poderia ter existido. Mas não. Por acaso. Daí a necessidade de a criar, como mito recriado. Até porque só os mitos têm realidade. E como nos mitos, os mitos criam a si próprios, falando.

A estátua se torna objeto/tema/metáfora do romance e agente na narrativa, como uma possibilidade criadora de passados e de diferentes perspectivas sobre este, como que contrapondo e sobrepondo modos de consciência distintos. Transformando a estátua em agente narrativo, Pepetela anuncia que Alexandre se misturou à terra cuvale ao nascer - pela boca, pelo corpo, pelo sangue. Ao por a dúvida sobre se a mordeu ou beijou-a, o autor faz emergir ideias de contradições e ambiguidades das experiências que serão vividas pelo protagonista e as distintas perspectivas que virão à tona sobre os acontecimentos.

Na sequência ao primeiro capítulo, chamado de “A Boca”, diferentes narrativas contextualizam os movimentos do pai de Alexandre pelo sul de Angola no final do século XIX, entre estes a experiência da família em terras de diferentes grupos étnicos, descrevendo também os diferentes movimentos dos povos cuvale, pela lida com o gado e ante a presença colonial. Durante os capítulos iniciais, o sul de Angola é narrado como um lugar de movimentos e disputas pela ocupação humana da terra, pelo comércio, pelo gado, pelas crenças e pela guerra. As grandes tensões se dão entre colonos portugueses, bôeres, ingleses e as populações tradicionais que se movimentavam há tempos pela região.

A experiência do colonialismo reinscrita por Pepetela rememora um passado episódico de conflitos, com as sucessivas guerras contra as populações nativas na região Sul, que evidenciam a opressão e que reforçam a reflexividade sobre a alteridade entre o que é o "colonial" e o que é o "nacional". Nesses casos, a violência racial também é descrita através de narrativas que trazem à luz a memória de resistência e de escravidão, do trabalho forçado, da classificação e da 
segregação das populações e outras formas violentas e sutis de discriminação, traduzidas para o presente. Bem como também revelam as angústias morais dos sujeitos diante das contradições e da violência colonial, impositiva, classificatória e segregacionista. A experiência de Alexandre, mediada pela da estátua, vai se constituindo como contraponto aos maniqueísmos e diante das experiências cuvales, como a de Vilonda, personagem que vivia transumando os bois e a vida e que será vítima de um desfecho trágico do encontro colonial.

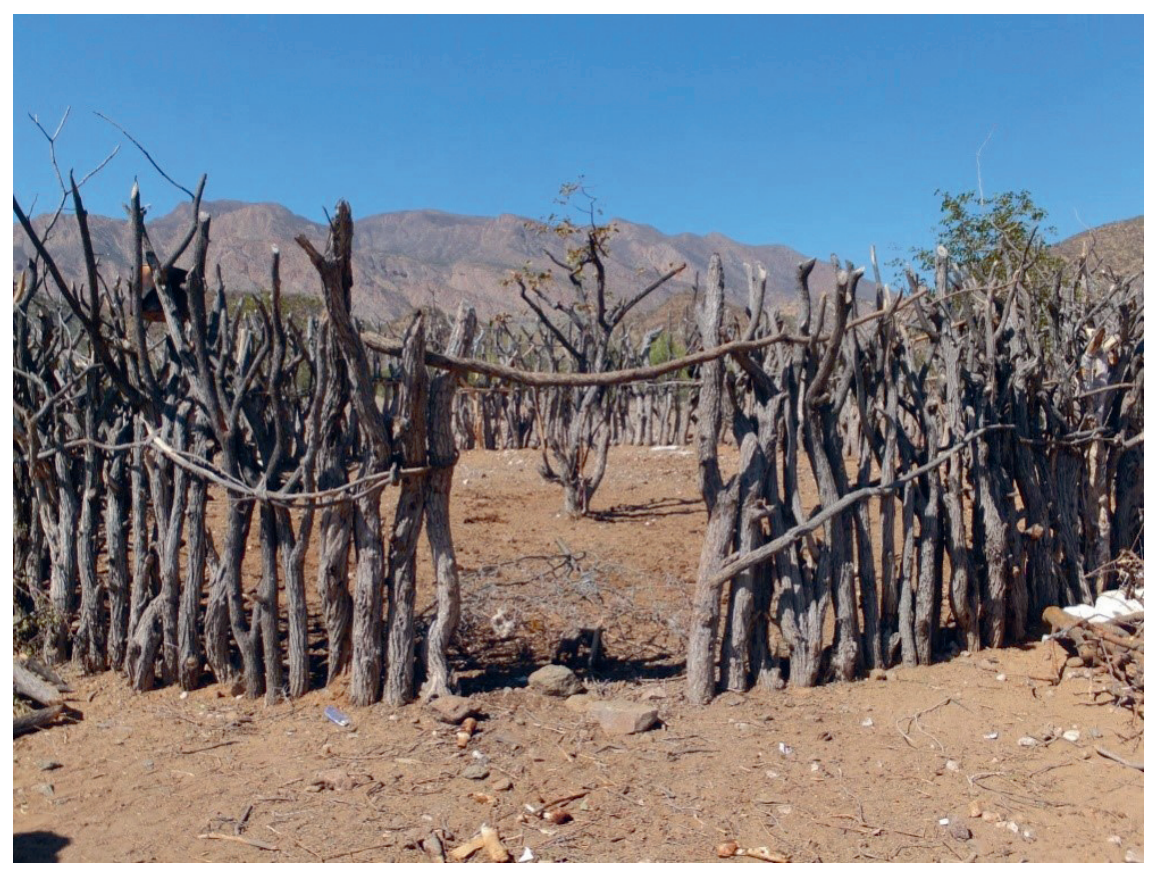

Figura 11.1 - Curral de gado do deserto do Namibe. Fonte: foto de Nazareno Campos, 2015.

\section{Colonialismo, racismo e nação ao sul de Angola}

Em Yaka (1984), os subtítulos dos capítulos fazem menção às datas que marcam episódios em que ocorreram conflitos entre o exército, ou a polícia colonial, e alguns "grupos étnicos" da região sul de Angola. Conflitos que envolveram ataques militares portuguses e a resistência de diferentes "etnias" consideradas rebeldes. Conflitos armados que ficaram conhecidos como "guerra de pacificação" ou "guerra preta", como aqueles retratados na obra do historiador René Pélissier (1986).

No romance, guerras que ocorreram entre 1890/1904, 1917, 1940/41, 1961 
e 1975 são narradas na perspectiva de Alexandre e da estátua. ${ }^{47}$ Alguns nomes são evidenciados como "heróis" da resistência ao colonialismo, além de localidades e ações que mitificaram a memória daqueles conflitos. Pepetela (1984) constrói a trajetória biográfica de Alexandre Semedo como eixo estrutural, sobrepondo-a à cronologia da guerra e marcada pela convivência da eterna ameaça de que as guerras coloniais e as revoltas anticoloniais chegassem um dia a Benguela, principal cidade colonial da região Sul. Essa memória da guerra como uma marca do colonialismo aparece associada à justificativa racista da pacificação dos povos ditos "não assimilados" ou daqueles que não aceitavam as regras da subserviência, do trabalho colonial ou da propriedade privada e comercial da terra.O sobrenome do protagonista, Alexandre Semedo, é uma referência irônica ao medo que sempre rondou os colonos ao sul de Angola, durante o período das guerras. Desde sua infância, Alexandre vivera tentando enganar o medo que sempre sentira das sublevações dos povos do interior. "Enquanto houver negros viveremos no medo[!]" Exclama Alexandre Semedo, logo nos primeiros tempos em que era um adulto e recém-casado. A constante ameaça que rondava os habitantes de Benguela era de que a guerra chegasse muito próxima da cidade ou mesmo ao seu interior, e isso sempre punha pânico em seus habitantes. Efetivamente, a guerra só chegará a acontecer na cidade nos anos finais da luta pela independência do domínio colonial, em 1975, quando Alexandre já estava velho e no fim da vida.

Se por um lado o estado colonial português era opressor e racista - as campanhas bélicas de Angola, o trabalho forçado, o "Acto Colonial” e a legislação em vigência na época demonstram isso ${ }^{48}$ - por outro lado, no decorrer da narrativa de Yaka (1984), além da memória sobre essas evidências, são descritpos atitudes e diálogos com ênfase às circunstâncias possíveis em que o racismo colonial se fazia presente. São representações criativas de situações imaginárias em que a sociedade colonial apresenta-se também repleta de racismo, primeiro, pelo variado número de designadores retóricos com base na cor ou raça que aparecem no decorrer da narrativa e, segundo, pelas distintas situações de contraste em que emergem essas retóricas, evidenciando um racismo cotidiano. ${ }^{49}$ Em Yaka (1984), "branco de primeira", "branco de segunda", apenas "branco", "mulato", "negro", "cafre", "preto" e "cabrito" são designações comuns que aparecem descre-

47 Sobre os conflitos de 1890/1904, de 1917 e de 1940/41 contra os povos do interior: "bailundos" ou "ovimbundos" e "cuvales", ver Pélissier (1986).

48 Ver, por exemplo, o Ato Colonial, o Estatuto Político Civil e Criminal dos Indígenas, o Código do Trabalho dos Indígenas nas Colônias Portuguesas de África, que podem ser consultados nos anexos do livro de Thomaz (2002).

49 Nos anexos da mesma obra citada na nota anterior, pode-se recorrer à legislação colonial para se perceber como era normatizado o racismo através de categorias classificatórias definidoras de direitos, como: indígenas, assimilados e civilizados na primeira metade do século XX. 
vendo distintos personagens e também envolvendo muitas situações de diálogos e conflitos em que emergem significados geralmente depreciativos dos mesmos. De maneira geral, os "não brancos" são "os outros" do estado colonial, e por isso são ridicularizados e considerados uma ameaça à "civilização". Expressões como "isso já é um negro civilizado!" (PEPETELA, 1984, P. 108) se repetem algumas vezes nas falas dos personagens do romance. São vozes de "brancos de primeira" ou "de segunda", nascidos na metrópole ou na colônia, a utilizarem de estereótipos coloniais depreciativos em relação aos "não brancos", sejam eles "mulatos", "negros", "pretos", "cafres" ou "cabritos". Cada palavra continha em seu uso retórico um significado situacional e relacional específicos, que são expressos em sua complexidade e singularidade no romance. A visibilidade desses termos é uma estratégia provocativa do autor para questionar reflexivamente sobre os significantes coloniais da diferença.

O personagem Aquiles de Aragão Semedo, filho de Alexandre, não poupava desaforos aos que chamava de "negros" e "mulatos", nem no trabalho onde comandava o serviço braçal de alguns homens, nem no lazer dos encontros de bar e de futebol. Não perdia a oportunidade de falar mal, com ofensas e palavrões, dos "negros" e "mulatos" que atravessassem a sua frente. Apesar disso, um dos seus maiores amigos desde os tempos de escola era um "negro", o Damião. Mas, segundo o romance, "Damião para ele não era negro, era um amigo. Negros eram esses trabalhadores matumbos e mangonheiros a quem era preciso surrar para trabalharem. Negro era o Alves, jogador do Benfica e o Jacinto, jogador do Portugal” (PEPETELA, 1984, p. 141). De qualquer maneira, também “já partira o focinho a um sacristão branco que insultou o Damião de seu negro da merda e negra era mas é a mãe do sacristão que, por sinal, até era loiro" (PEPETELA, 1984, p. 141). Narrativas como essas apresentam uma retórica ambivalente e situacional na individualização das relações que imperavam como dispositivos de aproximação ou de distanciamento pelos critérios racializados do colonialismo. "Negro" era sinônimo de incivilizado, imoral, atrasado, serviçal e quantos outros depreciativos sociais pudessem ser acionados. Estava na ponta negativa da hierarquia de valores, enquanto branco de primeira, na ponta mais alta desta. Todas as outras formas de nomear com critérios raciais, fenotípicos, linguísticos e culturais durante os tempos coloniais posicionavam lugares entremeios desses opostos.

Num sábado, meio-dia, terminado o trabalho, Aquiles se reuniu com Damião e mais alguns amigos no bar e resolveram ir caçar animais silvestres. Eram tempos de guerra no interior rural, pois havia estourado a revolta de alguns grupos "cuvales", também chamados pejorativamente de "mucubais" pelos "portugueses". Aquiles e seus amigos sabiam disso e mesmo assim resolveram tomar a estrada que dava para áreas próximas da revolta. Aquiles dizia e repetia não ter medo da revolta e que se algum "mucubal" lhe cruzasse o caminho, atirava para matar. O grupo resolve então parar em algum ponto do interior para iniciar a ca- 
çada. Curiosos, por dizerem nunca terem visto um "mucubal”, aproximam-se do local onde está o acampamento onde vivem pacificamente duas famílias de "mucubais", afastadas da área de conflito e que não estavam envolvidas na revolta. Durante a caçada, Aquiles vê um "mucubal" no mato e atira traiçoeiramente. O seu nome é Tyenda e ele cai morto. Vilonda, amigo de Tyenda, e que estava próximo do acontecido, viu quando o "branco" atirou, puxou da azagaia no mesmo instante e acertou Aquiles Semedo, matando-o. Alexandre Semedo, pai de Aquiles, quando soube do episódio, recusou-se ir ao enterro do filho, ficou silencioso e pensativo, com uma ideia fixa a persegui-lo, "matei Aquiles, matei meu filho. Eduquei-o dessa maneira superior porque branco" (PEPETELA, 1984, p. 188).

Foram essas mesmas ideias de superioridade que mataram Aquiles. Sentimentos de desprezo pelo "outro", estigmatizado pela ideia de "inferioridade" ou de "humanidade" menor. Argumentos justificados por determinismos de superioridade biológica, cultural e moral do "branco" sobre o "não branco" e que compunham a lógica hierárquica do racismo colonial. Quando Alexandre Semedo faz a afirmação autocrítica acima, ele está ponderando pela consciência e pela emoção, pela primeira vez durante sua vida, sobre a lógica que sustentou o racismo de que "brancos" e "não brancos" foram vítimas e algozes. Com a morte do filho por sua arrogância, Alexandre aciona a dupla consciência, não é nem mucubal nem colono, nem europeu nem indígena, mas pode de algum modo se ver como se fosse os dois.

No último capítulo do romance, a família de Alexandre Semedo vive na cidade de Benguela no ano de 1975, pouco antes da independência do país. Alexandre nasceu há muitos anos atrás, em 1890, e é filho de pai português degredado e de uma "branca" também nascida na colônia. Aos oitenta e cinco anos se tornara o patriarca de uma grande família, com filhos, genros, noras, netos e bisnetos. Chico, o neto "mulato" de Alexandre, é filho de uma filha que ele teve no passado com Joana, uma "negra" empregada de sua casa e a quem no passado sua esposa deu algum dinheiro para desaparecer da vida da família. O neto Chico só procurou Alexandre depois de adulto e passou a frequentar a casa do patriarca com a sua aprovação, mesmo com os olhares contrariados da maioria dos outros familiares. A família de Alexandre, por ascendência ou descendência, vem e vai entre muitos desígnios imprecisos no quadro complexo das relações e hierarquias do colonialismo.

Dias de transformações políticas se aproximavam, e a família de Alexandre sente que vivia a tensão dos momentos decisivos para a independência de Angola e resolveu se reunir na casa do patriarca para debater o assunto. $O$ convite foi feito pelo neto Xandinho, que era funcionário da administração colonial, e foi estendido a todos os familiares, inclusive a Chico, o mulato, considerado por alguns como o neto bastardo. Nem todos aceitaram o convite, muitos declinaram alegando outros motivos, só Dionísio foi mais explícito, dizendo "nem quero 
ouvir falar deste filho da puta de mulato da merda!" (PEPETELA, 1984, p. 250), negando o convite e se referindo de maneira agressiva e racializada ao neto Chico.

Durante a reunião, os poucos membros da família que estavam presentes discutiam sobre o possível fim do "colonialismo" e os momentos de transição que se seguiriam, quando Xandinho, preocupado com a sua situação de administrador colonial, exclamou que com a independência vão lhe acusar de colonialista, vão dizer que nem sequer ele é angolano, apesar de três gerações de sua família terem nascido e vivido em Angola. Todos os outros presentes fingem não lhe ouvir até que Xandinho insiste no ponto, retomando suas colocações. "Também temos sangue negro na família. Está aqui o Chico para o provar" (PEPETELA, 1984, p. 253). Os outros se entreolharam e depois "fitaram o mulato" e foi então que Chico respondeu exortando interrogativamente a mágoa que sempre teve de seus familiares. "Esse sangue negro sempre foi uma mancha na família, exceto para o avô. Sofri por causa disso. Agora é uma medalha?" (PEPETELA, 1984, p. 253) As palavras de Chico criaram um mal estar e todos se calaram. A reunião se desfez e a nenhuma conclusão se chegou naquele momento.

Os Semedo ficaram divididos e eles são a expressão da trajetória do patriarca, alguns contrários ao movimento de independência, outros a favor, outros nem para um lado ou para o outro, revelando as idiossincrasias das opções de cada um. O medo de Xandinho, em relação aos desdobramentos dos últimos acontecimentos em Angola, paulatinamente leva-lhe à loucura. Ele começa a delirar imaginando que a sua condição de administrador colonial, que um dia the dera algum prestígio, agora lhe trará sérias complicações e até mesmo comprometerá sua sobrevivência numa Angola independente. Ele tentava convencer si próprio e os membros da família de que era legítimo o seu lugar ocupado numa sociedade independente, pois a genealogia da família seria a prova de que eles sempre fizeram parte de Angola, apelando também para o argumento do parentesco, antes negado por ele mesmo, com o "mulato" Chico, que agora é alguém que passa a ser visto com mais legitimidade de pertencer ao país independente, por carregar o significante visível da cor como vínculo mais que legítimo do parentesco que ligaria a família Semedo biologicamente e fenotipicamente à ancestralidade da "nação angolana", porque negra ou porque nativa.

Enquanto Xandinho passava os dias a delirar, demonstrando a angústia e o medo daqueles que se sentiam ameaçados pela descolonização, os outros membros da família tentavam se arrumar na vida e se adaptar aos últimos acontecimentos na cidade de Benguela, distribuindo-se entre os partidos políticos que passam a surgir. Quando sentem que a situação do colonialismo é insustentável, e a independência, irreversível, juntam alguns caminhões e os bens que têm e fogem para a África do Sul, com medo de perderem os bens e de serem responsabilizados pelo colonialismo. Os únicos membros da família Semedo que permaneceram em Angola são o patriarca Alexandre e o bisneto Joel, além do neto Chico e sua famí- 
lia. Chico resolve não ingressar em nenhum movimento, e Joel ingressa no MPLA, no qual, ao lado de Ruca, seu "colega negro", vai para frente de combate quando a guerra se aproxima de Benguela e eclode o conflito entre o MPLA e a UNITA, esta última apoiada pela África do Sul. ${ }^{50}$ São diferentes gerações de uma mesma linhagem, com diferentes posições a depender das trajetórias pessoais vivenciadas e da forma com que a consciência política se constrói, ou de como Pepetela as imaginou como arquétipo do que ele entende por nação. A dupla consciência de Alexandre está novamente representada, agora pela tomada de posições de seus filhos e netos. A especificidade dos séculos de presença portuguesa e a memória social do exercício do racismo durante a experiência colonial em Angola, mas também da resistência contra ela, estabeleceu o reconhecimento da diferença raça/cor como marcador da alteridade social e cultural. As memórias do colonialismo estão intimamente relacionadas à experiência de sociedades que estiveram envolvidas por políticas oficiais de racismo e sob a condição colonial, embora isso não seja exclusividade delas.

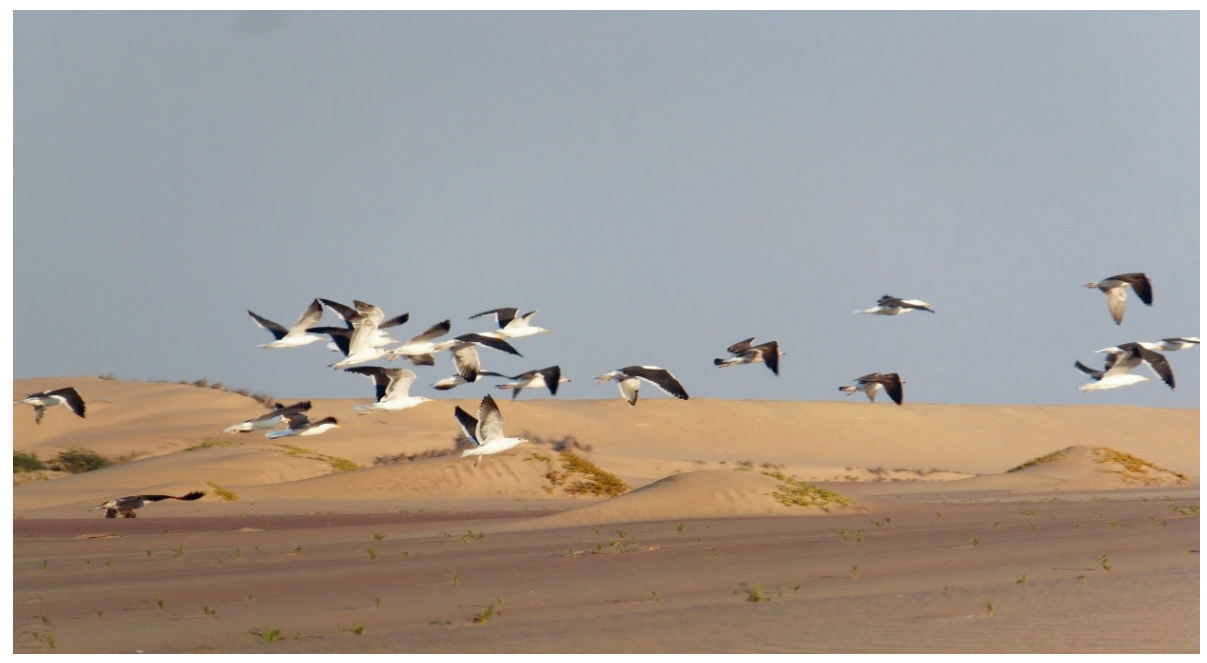

Figura 11.2 - Arrevoada no deserto. Fonte: foto de Nazareno Campos, 2005.

50 A guerra contra o colonialismo expôs de maneira significativa a experiência social do racismo. Muitos portugueses e descendentes fugiram de Angola durante a guerra colonial e migraram para a África do Sul, para o Brasil ou para Portugal. A revolta contra o colonialismo durante a guerra pela descolonização investira-se de uma postura que associava diretamente o colonialismo aos proprietários de terras e donos de comércio em Angola, e estes pelo estereótipo da raça/cor. As famílias de "brancos" que por muitas ou poucas gerações se fizeram em Angola, mantendo a "pureza" ou "misturando-se", passaram a ser identificadas pelo estereótipo de famílias de colonos. 


\section{Considerações finais}

Yaka (1984) foi escrito nos primeiros anos depois da independência e é um romance que fala da integração das diferentes experiências de vida num projeto idealizado de nação, entendendo que esta é uma vontade política, uma construção de identificação com as pessoas, uma percepção de compreensão sobre os acontecimentos e os lugares, uma vontade de se viver juntos a partir de algum projeto de emancipação, mesmo que se reconheçam as diferenças. Nesse sentido, a narrativa que se constrói como passado no romance é aquela que idealiza incluir as histórias de todos os que escolheram viver no novo país, um projeto de nação, como vontade de passado e de futuro (Marcon, 2005), nesse caso situando a região sul de Angola como cenário - o que não é por acaso. O Sul será o terreno de fortes tensões durante a guerra civil que surgirá após a independência.

Isso não significa que Pepetela deixe de reconhecer que, tanto na nação idealizada como na nação realizada, os conflitos raciais e os estereótipos que marcam a diferença pelo fenótipo tenham deixado de existir após a descolonização, assim como outras questões de tensões e diferenças. Com a independência, não se superaram muitos dos problemas evidenciados em Yaka (1984) e em outros romances de Pepetela. Suas narrativas sobre o passado colonial subvertem-no para preencher os vazios de "memória na perspectiva nacional" ainda não constituída e sistematizada, o que implica também num inventário de problemáticas consideradas presentes. Nesses casos, a memória do racismo e a memória sobre as contradições se confundem com a memória do colonialismo, e dessas narrativas emerge a saliência da sobreposição entre ambos.

Em Yaka (1984), no decorrer da narrativa em que Alexandre Semedo vivia a crise da dupla consciência sobre sua identidade de colono e colonizado, pelo fato de ser "branco", filho de português, mas nascido em Angola, Pepetela antevê a crise do sujeito pós-colonial, para além de cenários nacionais bem definidos. Só no final da vida de Alexandre, que coincide com o ano da independência do país, em 1975, é que ele se convence de que é preciso escolher entre "ser" e "não ser" angolano, reconhecendo que, para além de nascer num lugar, uma identidade nacional é uma questão de sentimento, de comprometimento e de escolhas. Alexandre sempre convivera com a dúvida, mas ele não foge de Angola como a maioria de seus descendentes no momento da independência. Quando a velhice chega e a morte se aproxima é que ele parece compreender as contradições e as ambiguidades que cercaram o percurso de sua trajetória de vida, com a companhia da estátua Yaka sempre lhe fazendo lembrar-se de seu vínculo com a terra e com os signos míticos não portugueses e não brancos que lhe deram sentido à vida, sempre lhe fazendo lembrar de que sua própria trajetória é e foi marcada por contradições. 
Por fim, Yaka (1984) é muito mais sobre a nação como uma construção social possível, num cenário de trajetórias de vidas com experiências que se cruzam paradoxalmente entre a harmonia e o conflito e muito menos sobre a saga de uma família de colonos em Angola. É mais uma narrativa sobre a construção da nação, reconhecendo as ambivalências da identificação dos sujeitos e grupos com os projetos nacionais e as perspectivas que deles emergem, do que uma apologia aos substancialismos. Uma narrativa que questiona o que é "ser" e "não ser" nativo e colono, branco e preto, bem como quais os muitos modos possíveis de ser angolano, volatizando fronteiras físicas ou metafóricas entre vidas que se movem e se relacionam.

As experiências globais contemporâneas do contexto colonial/pós-colonial, desde o último quartel do século XX, abriram novos espaços para a reflexão sobre o desenraizamento e o nomadismo, mesmo em tempos de evidências sobre a continuidade da força aglutinadora dos sentimentos nacionais. Yaka expõe esse sintoma da crise do sujeito centrado em um contexto cambaleante da modernidade, como aponta Stuart Hall (2002), demonstrando o quanto elas podem ser deslizantes, descentradas e ambivalentes. As experiências e as memórias sobre o sul de Angola estão implicadas por tal condição e num contexto de intensas migrações e transumâncias, embora instituições políticas hegemônicas teimem em demarcar fronteiras que muitas vezes não fazem sentido para os que ali viveram ou vivem nos dias hoje.

\section{Referências}

BAKHTIN, M. Questões de literatura e de estética: a teoria do romance. São Paulo: Unesp, 1998.

BARTHES, R. O rumor da língua. São Paulo: Martins Fontes, 2004.

BAUMAN, Z. Modernidade e ambivalência. Rio de Janeiro: Jorge Zahar, 1999.

BHABHA, H. K. O local da cultura. Belo Horizonte: UFMG, 1998.

CANCLINI, N. G. Culturas híbridas: estratégias para entrar e sair da modernidade. São Paulo: Edusp, 1998.

CLIFFORD, J. Routes: travel and translations in the late twentieh century. Cambridge: Harvard University Press, 1997.

ENNES, M.; MARCON, F. Das identidades aos processos identitários: repensando conexões entre cultura e poder. Sociologias, Porto Alegre, ano 16, n. 35, p. 274-305, 2014.

GILROY, P. O Atlântico negro: modernidade e dupla consciência. São Paulo: Editora 34; Rio de Janeiro: Ucam, 2001. 
HALL, S. A identidade cultural na pós-modernidade. 7. ed. Rio de Janeiro: DP\&A, 2002.

KANDJIMBO, L. Apologia de Kalitangi: ensaio e crítica. Luanda: Inald, 1997.

LEITE, A. M. Angola. In: CHABAL, P.; AUGEL, M. P.; BROOKSHAW, D.; LEITE, A. M.; SHAW, C. The postcolonial literature of lusophone Africa. London: Hurst \& Company, 1996. p. 115-123.

MARCON, F. Antirracismo. Revista de Estudos de Cultura, n. 2, p. 61-73, 2015.

. Diálogos transatlânticos: identidade e nação entre Brasil e Angola. Florianópolis: Letras Contemporâneas, 2005.

. Os romances de Pepetela e a imaginação da nação em Angola. In: História Revista, Goiânia, v. 16, n. 1, 2011. p. 31-51.

MATA, I. L. S. Ficção e história na obra de Pepetela: dimensão extratextual e eficácia. 2003. Dissertação (Doutorado em Literaturas Africanas de Expressão Portuguesa) - Faculdade de Letras da Universidade de Lisboa, Lisboa, 2003.

PÉLISSIER, R. Histórias das campanhas de Angola: resistência e revoltas (1845-1941). Lisboa: Editorial Estampa, 1986. v. 2.

PEPETELA. Yaka. São Paulo: Ática, 1984. (Coleção Autores Africanos, v. 23).

THOMAZ, O. R. Ecos do Atlântico Sul. Rio de Janeiro: UFRJ, 2002. 